\title{
Economics of Households in Pacific Island Countries: A Case Study of Vanuatu and Tuvalu
}

\author{
Ranjila Devi Singh, Sarah L. Hemstock \\ Pacific Centre for Environment and Sustainable Development, University of the South Pacific, Suva, Fiji \\ Email: s11049662@student.usp.ac.fj, sarah.hemstock@usp.ac.fj
}

Received July 29, 2013; revised August 29, 2013; accepted September 10, 2013

Copyright (C) 2013 Ranjila Devi Singh, Sarah L. Hemstock. This is an open access article distributed under the Creative Commons Attribution License, which permits unrestricted use, distribution, and reproduction in any medium, provided the original work is properly cited.

\begin{abstract}
The source of livelihood varies amongst the Pacific Island Countries and also within a country; between urban and rural areas. Most Pacific Island Countries (PICs) and their households rely on subsistence activities and agriculture for their livelihood. This research was based on surveys conducted in Piliura and Tassiriki villages in Vanuatu and Vaiaku, Senala and Tumaseu villages in Tuvalu, which involved developing a methodology for household surveys to elucidate issues linked to livelihood. The analysis revealed that the major source of household income in Vanuatu study sites was from the sale of products, while in Funafuti (Tuvalu) households earned the majority of their income from wages/salaries. However, in Tumaseu village (Tuvalu) the households generated their source of income from both wages and sale of products. In all the study sites, food was the major household expense. This study was aimed at allowing researchers and decision makers a better understanding of the economic realities for households in PICs.
\end{abstract}

Keywords: PICs; Households; Livelihood

\section{Introduction}

Much existing literature indicates that the people of the Pacific Island Countries (PICs) rely on subsistence activities and agriculture for their livelihood, with remittances contributing significantly to income. This study aims to give researchers and decision makers a better understanding of the economic realities of household income and expenditure in PICs.

\section{Study Sites}

Five sites took part in the study, two in Vanuatu and three in Tuvalu. These two Pacific Island Countries were selected as they varied geographically, economically and socially, so it should provide a broad basis on which to gain in depth knowledge on household economics.

\subsection{Vanuatu}

Vanuatu has 80 islands with the total land area 12,190 $\mathrm{km}^{2}$ and lies between 13 - 21 degrees south and 166 171 degrees east [1]. Of the 80 islands in Vanuatu, 65 are inhabited and its exclusive economic zone is 700,000 $\mathrm{km}^{2}$ [2]. Port Vila is the capital of Vanuatu located on the Efate Island and the largest island in Vanuatu is Espiritu
Santo [3]. The main islands are linked by air and the remote ones by boat. The population of Vanuatu is 234,023 and 76 percent of the population live in rural areas [2,4]. The majority (98.7 percent) of the population is of ni-vanuatu ethnicity and the reminder 1.3 percent are of part ni-vanuatu, other Melanesian, Polynesian, Micronesian, European and Chinese [3]. The major economic activities in Vanuatu are agriculture, forestry and fishing and tourism sector is also increasing [1,5]. Copra, kava, cocoa, coffee, taro, yams, fruits and vegetables, beef and fish are the main agricultural products $[1,6]$. Food and fish freezing, wood processing and meat canning are the industries present in Vanuatu [6]. The two communities from Vanuatu are Piliura and Tassiriki village. Piliura village is in Pele Island which is located seven kilometres off the north coast of Vanuatu's main island, Efate. Pele Island falls under the Shefa province and has four villages namely Laonamoa, Piliura, Worearu and Worasifiu with 62 households and 330 people [4]. There are 22 households and 136 people living in Piliura village. The locals depend on subsistence activities such as fishing, agriculture, eco-tourism and selling handicrafts. The children from Piliura village attend primary school on the island. For further education, the students have to travel to Port Vila. Rainwater is the main source of drinking 
water which is collected in village tanks, household tanks and plastic buckets and containers. Tassiriki village is located in Moso Island which is close to Efate Island. It also belongs to Shefa province. The island is covered with extensive areas of mangroves. There are two villages on Moso Island namely Tassiriki (Sunae) and Sounai. Tassiriki village has 35 households and 297 people reside in the village. The locals earn their living by farming activities, selling charcoal, selling fish, handicrafts and some tourism activities. Charcoal and vegetables are sold at the Port Vila market. The village has a primary school but for further education the students travel to Port Vila. The mode of transport from Moso Island to Efate Island is by boat. Drinking water is collected in concrete tanks which are often shared between few households and some have their own water tanks. Plastic buckets and containers also supplement collection of rainwater. Groundwater is used for bathing and washing.

\subsection{Tuvalu}

The island of Tuvalu lies in the Western South Pacific, its coordinates are 176 - 180 degrees east and 5 11degerees south [1]. The total land area is $26 \mathrm{~km}^{2}$ with five true atolls and four raised limestone reef islands [7]; [1]. Tuvalu's exclusive economic zone (EEZ) extends to $900,000 \mathrm{~km}^{2}$ and has great fish stocks [8]. The main island of Tuvalu is Funafuti and the capital is Fongafale [9]. The population of Tuvalu was estimated to be 11,206 in 2011 [10]. English, Tuvaluan and Kiribati are the three main languages [9]. All the islands have primary school but for secondary school the students travel to Vaitupu Island. For further education the students travel to other Pacific island countries or to Funafuti which has a University of the South Pacific Campus, commercial school - Maleta Kapane Halo Computer and Typing School and Tuvalu Maritime Training Institute [11]. The economy of Tuvalu heavily relies on imported food and fuel [9]. Subsistence agriculture and fisheries are major activities for the Tuvaluans; tourism, EEZ fishing licence fees and remittances from Tuvaluans employed abroad, mainly as seafarers, is also a source of income [9]. The three communities from Tuvalu were Vaiaku and Senala village from Funafuti Island and Tumaseu village from Vaitupu Island. Vaiaku village has 72 households and the population of Vaiaku village is 485 [11]. There are 142 households in Senala village and the village has a population of 909 [11]. People migrate from outer islands to Funafuti for further education, better medical facilities and employment opportunities [11]. Motorbikes, cars, trucks and bicycles are the main modes of transportation on the islands [11]. The main sources of income in Funafuti are employment, remittances and subsistence fishing, cutting toddy, handicrafts, farming and livestock (pig and chi- cken) rearing [11]. Agriculture in Funafuti is limited as there are high numbers of houses and lack of land, the land available is used for Pulaka (Cyrtosperma chamissonis) cultivation and home gardening is common [11]. Tumaseu village has 53 households and a total population of 217 people [12]. The only public secondary school run by government is Motufoua Secondary School which is located on the island of Vaitupu and is a boarding school where students from other islands come to complete secondary school [12]. The main health facility on the island that is the clinic which is located in Saniuta village and accessible to all eight villages and Motufoua health clinic which is close to Motufoua Secondary School is for school students and the teachers only. However, there are no doctors in Vaitupu hence serious cases need to be referred to Funafuti [12]. Vaitupu people are mostly self-employed such as operating canteens and small shops, fishing, gambling (known as bingo), and a few owning night clubs, motorbike hiring, loan scheme business and barber shop [12]. The sources of cash income are from land leases, remittances and pension, while, subsistence living is from feeding pigs, agricultural activities and toddy cutting [12]. Women in Vaitupu play a major role, they have formed organization known as "Fafine Vaitupu Aoao" which means women from the age of 18 - 69 years [12]. They are involved in subsistence activities such as handicraft making and selling (fans, mats, local brooms, coconut oil), feeding livestock and farming, some are also employed and self-employed [12].

\section{Methodology}

This study was a non-experimental design involving household surveys. A survey was undertaken to gain in-depth knowledge on economic characteristic of the households. The respondents were questioned on their education level, annual household income, main source of household income and who managed the household income. Major household expenses were also reveled by the survey. The household survey was given to the household with the explanation of the questions and the purpose of the survey in local language. It was ensured that an equal number of surveys were given to males and females of the community to eliminate gender bias. Table 1 illustrates the number of surveys obtained from each site and the number completed by male and female respondents.

The household surveys were translated in both Bislama and Tuvaluan languages. A total of 137 household surveys were carried out for this research. For the Vanuatu sites that is Piliura and Tassiriki villages a total of 38 household surveys were completed in July 2012. In Piliura village a total of 18 household surveys were carried out. The number of households present in Piliura village 
Table 1. The number of surveys obtained from each site and the percentage completed by male and female respondents.

\begin{tabular}{cccc}
\hline Study Site & Number of Surveys Obtained & Number Male & Number Female \\
\hline Vanuatu Sites (Piliura and Tassiriki) & 38 & 21 & 17 \\
Tuvalu Sites (Vaiaku, Senala and Tumaseu) & 99 & 45 & 54 \\
\hline
\end{tabular}

is 22 household's as a result only 18 household surveys were obtained. In Tassiriki village 20 household surveys were done and the total number of household present in Tassiriki village was 35 households. For the Tuvalu study sites: Vaiaku, Senala and Tumaseu villages a total of 99 household surveys were obtained. The household surveys from Vaiaku, Senala and Tumaseu were 36, 42 and 21 respectively. The research in Tuvalu was completed in November 2012.

Analysis of the household survey was done in Statistical Package for the Social Sciences (SPSS, version 16.0). It has a set of software tools that allows for data entry, data management, statistical analysis and presentation. Once all close ended questions were coded, inputted and analysed, frequency distributions and means were generated and comparisons of means were prepared to identify statistical relationships between the variables such as source of income and major household expense.

An inferential analysis-analysis of variance using a non-parametric hypothesis test (Mann-Whitney test) was conducted to test if there was any significant difference among the two locations (Piliura and Tassiriki village) for the variables surveyed. The null hypothesis was set to be that statistically there is no significant difference between Piliura and Tassiriki village. While the alternative hypothesis was set to be that statistically there is significant difference between the two locations. From the $\mathrm{p}$ value of Mann-Whitney test it can be found out if there is any statistically significant difference or no. If the $\mathrm{p}$ [Asymp. Sig. (2-tailed)] value is less than 0.05 the null hypothesis will be rejected and alternative hypothesis will be accepted and vice versa at five percent significant level. Similar, hypothesis test was done for the two islands in Tuvalu: Funafuti Island (Vaiaku and Senala village) and Vaitupu Island (Tumaseu village).

Therefore, the data for Piliura and Tassiriki village are analysed together as statistically no significant differences existed between the two locations except for main source of household income. Similarly, the data for Funafuti Island (Vaiaku and Senala village) and Vaitupu Island (Tumaseu village) are analysed together since there was no statistically significant difference between the two locations except for annual household income and source of income.

\section{Findings}

\subsection{Vanuatu}

Of the 38 survey respondents in Piliura and Tassiriki,
55.3 percent were male and 44.7 percent were female. The survey participant's year of birth ranged from 1938 to 1993 so participant ages ranged from 19 to 74 years. The number of adults in the households ranged from two to 12 people, with an average of four adults per household. While the number of children per household ranged from one to eight children, the average was two children per household. The interviewee's period of residence in their respective villages ranged from four years to 67 years, the average being 23 years. Figure 1 shows the education level of the respondents in Vanuatu study sites.

The levels of education for the samples surveyed in Piliura and Tassiriki villages show that majority of the respondents, 56.8 percent, have attained education till primary school. While 37.8 percent of the respondents went to secondary school and 5.4 percent have not received any schooling. Pele and Moso Island have a primary school, children from Piliura and Tassiriki travel by boat to Port Villa to attend higher schools. Once children have completed primary school the majorities leave education to help with income generating activities such as farming and fishing. Some of the locals have not attended schools this can be due to transportation and financial difficulties faced by those living in remote villages such as Piliura and Tassiriki.

Of the participants 14.8 percent had less than US\$ 221 (20000 Vatu) as their annual household income, 11.1 percent between US\$ 232 to US\$ 442 (21,000 Vatu to 40,000 Vatu), 11.1 percent between US\$ 453 to US\$ 664 (41,000 Vatu to 60,000 Vatu) and 62.9 percent had above US\$ 675 (61,000 Vatu). The average household income was US\$11,781 (106,0351 Vatu). Figure 2 highlights the main source of household income for Piliura village.

The main source of household income in Piliura village was generated through sales of products (62.4 per-

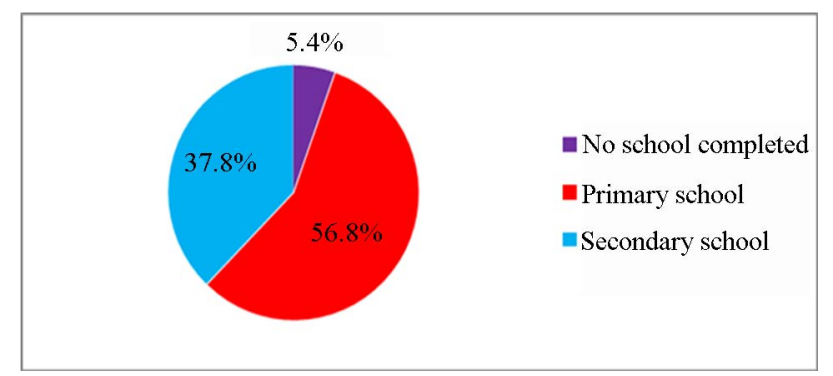

Figure 1. Educational levels of respondents from Piliura and Tassiriki villages, Vanuatu in year $2012(n=38)$. 
cent). Pele Island is a tourist site; Piliura locals sell handicrafts and sea shells to the tourists on the island. Handicrafts such as fans are weaved out of coconut and pandanus leaves, and necklaces made from coconut shells. Women were engaged in handicraft making and selling. People of Piliura village grow crops and vegetables and engage in fishing, these products are sold in Port Vila market to earn a living. Of the survey respondents 25 percent earned a living from wages and salary. The locals were employed as tour guides to the tourists and some of the locals travelled to Port Villa for employment. While 12.5 percent generated income from own business such as such as boat services and guest house rents to tourists and researchers. Figure $\mathbf{3}$ shows the main source of household income for Tassiriki village.

The majority of households (94.4 percent) generate income from sales of products such as fish, crops, firewood and charcoal Firewood and charcoal were the major products sold by Tassiriki locals. One bag of charcoal is sold for US\$11 (1000 Vatu). However, there are expenses involved in charcoal production and marketing such as buying of charcoal bags, transportation cost to market and market table fee. The household income for the households surveyed is managed by males, females, both males and females and families. Figure $\mathbf{4}$ highlights the management of household income.

Males manage the household income for the majority of the households surveyed (64.5 percent). Therefore in Piliura and Tassiriki villages there is gender division in household income management. Decision making for use

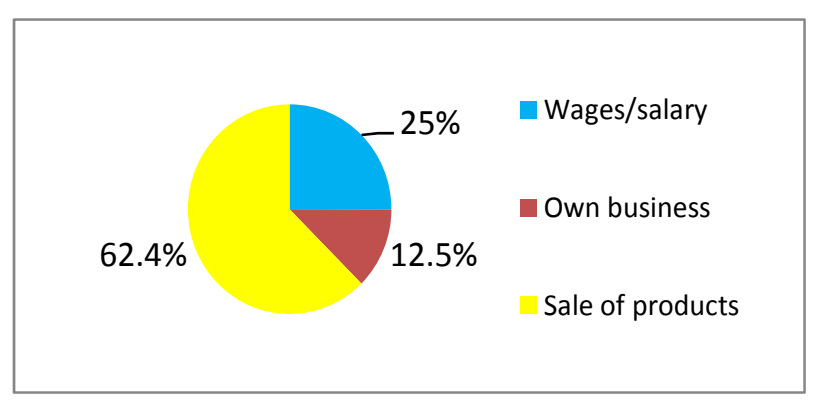

Figure 2. Main source of household income for Piliura, Vanuatu in year $2012(n=18)$.

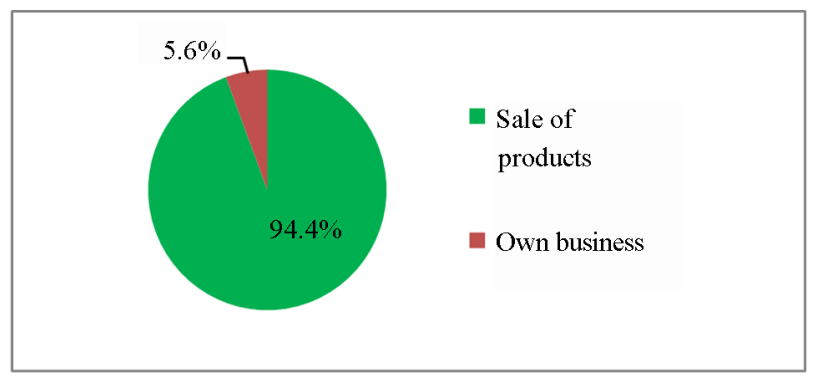

Figure 3. Main source of household income for Tassiriki, Vanuatu in year $2012(n=20)$. of household income in rural areas is mostly done by males this strongly agrees with [13]. Only in 19.4 percent of the households surveyed the household income is managed by females, in 12.9 percent by both males and females, and in 3.2 percent by the whole family. Food and education were found to be the major household expense for Piliura and Tassiriki locals. Figure 5 below displays major household expenses.

Food was the major household expense (62.2 percent), followed by education (29.7 percent), health care (5.4 percent) and transport (2.7 percent).

\subsection{Tuvalu}

Of the 99 survey respondents in Tuvalu, 45.5 percent were males and 54.5 percent were females. The survey participant's year of birth ranged from 1938 to 1993 so participants ages ranged from 19 to 74 years. The number of adults in the households surveyed ranged from two to 18 people with an average of six adults. While the number of children per household ranged from none to ten with an average of three children. The interviewee's period of residence in their respective villages ranged from one year to 74 years, the average being 24 years. Figure 6 below shows the level of education for the survey participants.

Majority of the respondents (52.2 percent) have completed their education till secondary school in Motufoua Secondary School which is a public school operated by government (located on Vaitupu Island) and Fetuvalu

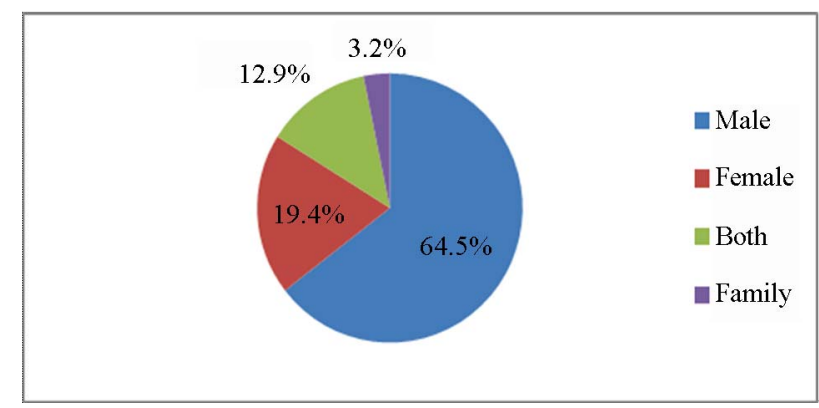

Figure 4. Management of household income in Piliura and Tassiriki villages, Vanuatu in year $2012(n=38)$.

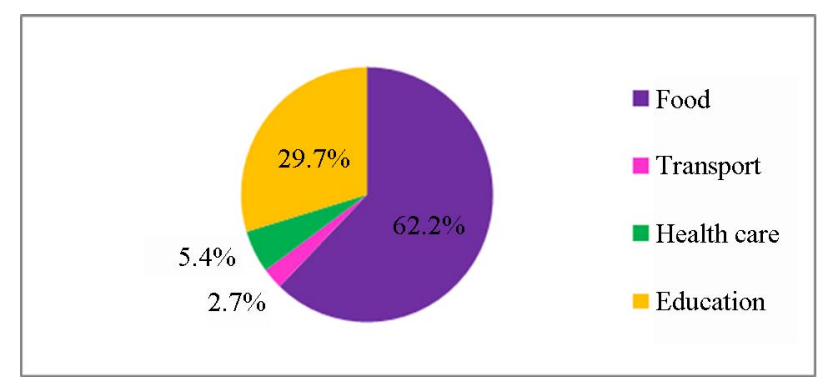

Figure 5. Major household expenses in Piliura and Tassiriki villages, Vanuatu in year $2012(n=38)$. 
Secondary School operated by Kalesia Kelisiano Tuvalu (See [11]). The students from other islands travel to Vaitupu Island to complete their secondary school education. Primary school has been completed by 32.6 percent of the population. Only 1.1 percent of the surveyed population did not attain any formal education. Primary school education is offered for free in Tuvalu. Amongst the surveyed 13 percent have attained education till diploma level and 1.1 percent has attained a master's degree. Tertiary education in Tuvalu is offered by Maleta Kapane Halo Computer and Typing School, University of the South Pacific Tuvalu Campus and Tuvalu Maritime Training Institute (See [11]). Students from Tuvalu also travel to other Pacific Island Countries to attain further education especially Fiji Islands. Figure 7 shows the annual household income for Vaiaku and Senala villages, Funafuti Island.

In Vaiaku and Senala villages, 21.6 percent of the respondents had less than US\$1025 (AUD\$ 1000) as their annual household income, 28.4 percent had annual household income between US\$ 1026 to US\$ 5127 (AUD\$ 1001 to AUD\$ 5000), 23.8 percent had between

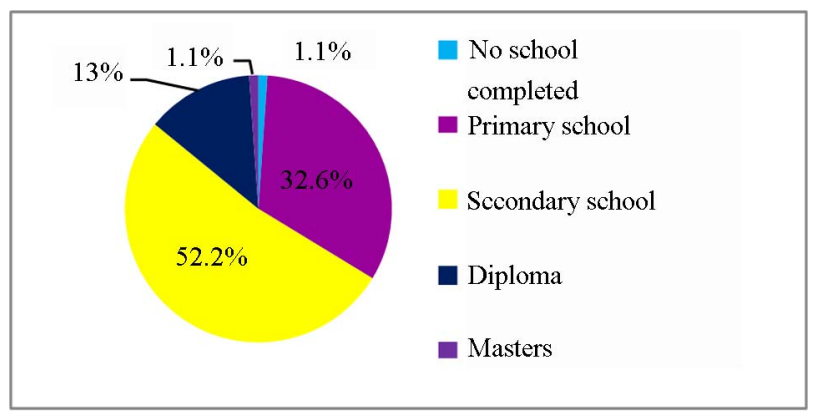

Figure 6. Educational levels of respondents from Vaiaku, Senala and Tumaseu villages, Tuvalu in year $2012(n=99)$.

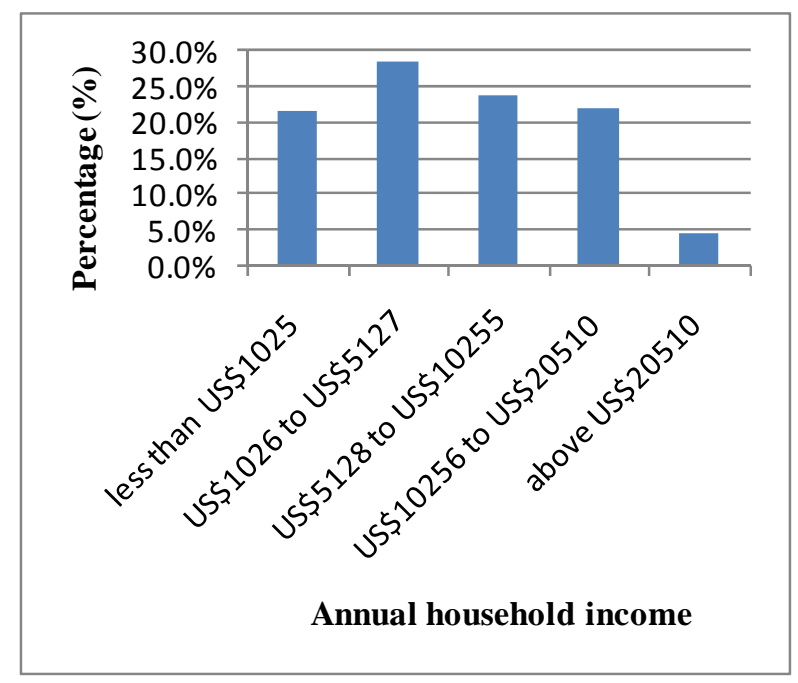

Figure 7. Annual household income for Vaiaku and Senala village, Funafuti Island, Tuvalu in year $2012(n=78)$.
US\$ 5128 to US\$ 10255 (AUD\$ 5001 to AUD\$ 10,000), 21.8 percent had between US\$10,256 to US\$20,510 (AUD\$ 10,001 to AUD\$ 20,000) and the remaining seven percent had their annual household income above US\$ 20,510 (AUD\$ 20,001). The highest annual household income amongst the respondents was US\$ 30,765 (AUD\$ 30,000), lowest income was US\$ 300 (AUD\$ 293) and the average household income for the respondents was US\$ 7533 (AUD\$ 7,357). Figure 8 highlights the main source of household income of Vaiaku and Senala villages, Funafuti Island.

Figure 9 shows the annual household income for Tumaseu village, Vaitupu Island.

In Tumaseu village, Vaitupu Island, 50 percent of the survey respondents had less than US\$1025 (AUD\$1000) as their annual household income. While 37.5 percent had annual household income between US\$ 1026 to US\$ 5127 (AUD\$ 1001 to AUD\$ 5000) and 12.5 percent had between US\$ 10,256 to US\$ 20,510 (AUD\$ 10,001 to AUD\$ 20,000). The highest annual household income amongst the respondents was US\$20,500 (AUD\$ 20,000) lowest income was US\$512 (AUD \$500) and the average household income for the respondents was US\$ 4589

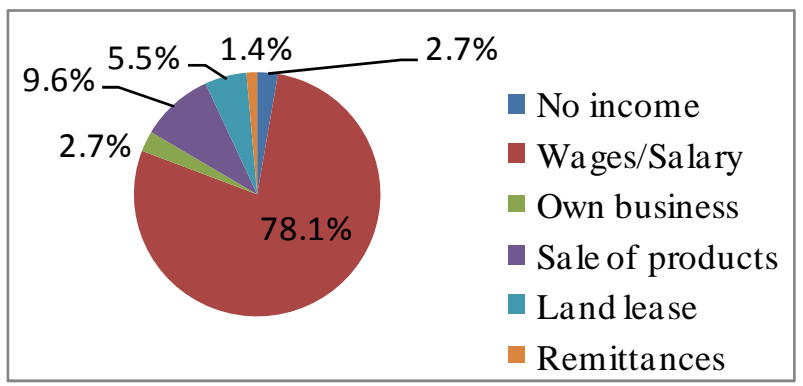

Figure 8. Main source of household income of Vaiaku and Senala villages Funafuti Island in year $2012(n=78)$.

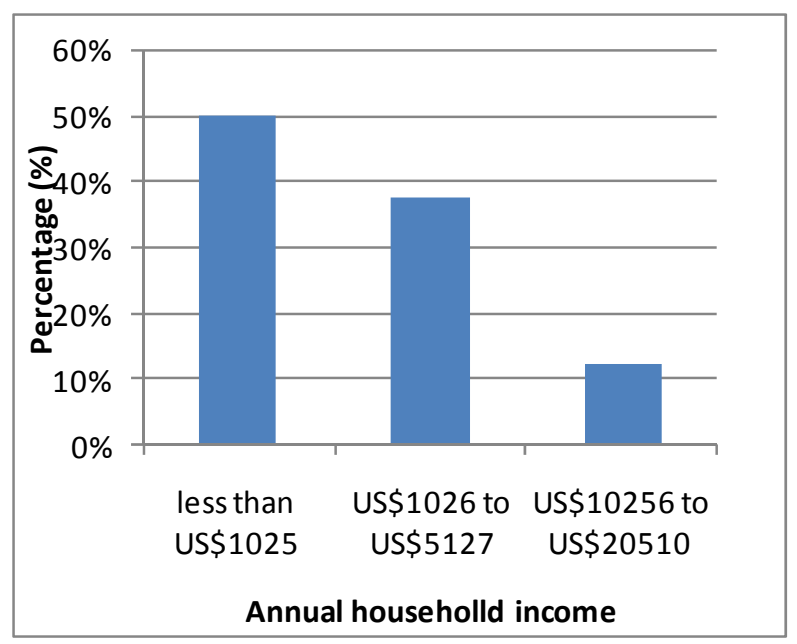

Figure 9. Annual household income for Tumaseu village, Vaitupu Island, Tuvalu in year $2012(n=21)$. 
(AUD\$ 4,477). Figure 10 displays the main source of household income of Tumaseu village Vaitupu Island.

Of the households surveyed 50 percent earned a living from employment. The locals were employed as seafearers, plant and machine operators, teachers, nurses, sales person, caretakers, agriculture officers, fisheries observers and other administrative positions in Island Kaupule and Government (see [12]). Whereas 33.3 percent earned a living from sale of products such as fish, coconut and handicrafts, 11.1 percent generated income from land lease and 5.6 percent earned living from own business such as shops (groceries shop, motor bike hire and repair, handicrafts, carpentry and commercial fishing business. Figure 11 displays the management of household income.

In 44.7 percent of the households surveyed the household income was managed by females, in 29.4 percent by males and in 12.9 percent by both males and females. Females dominated the management of household income in Tuvalu. In 8.2 percent of the households the whole family managed the household income. While in 2.4 percent of the households only elders managed the household income, in 1.2 percent of the households' children managed the household income and again in 1.2 percent of households cousins were responsible for management of household income. According to [11], in Vaiaku 56 households are headed by males and 17 households by females and in Senala 101 households are headed by male and 41 households by females [12] in-

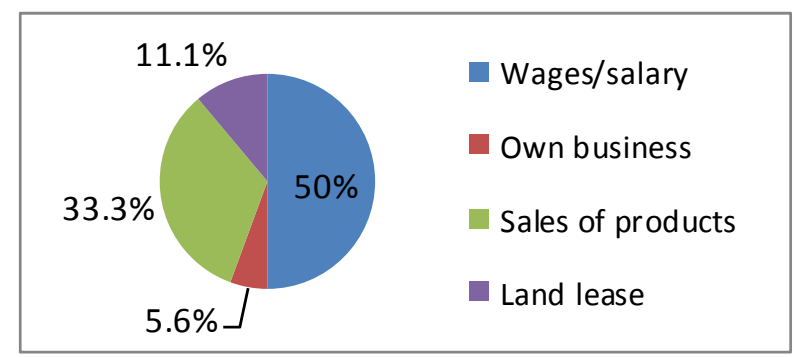

Figure 10. Source of income for Tumaseu village, Vaitupu Island Tuvalu in year $2012(n=21)$.

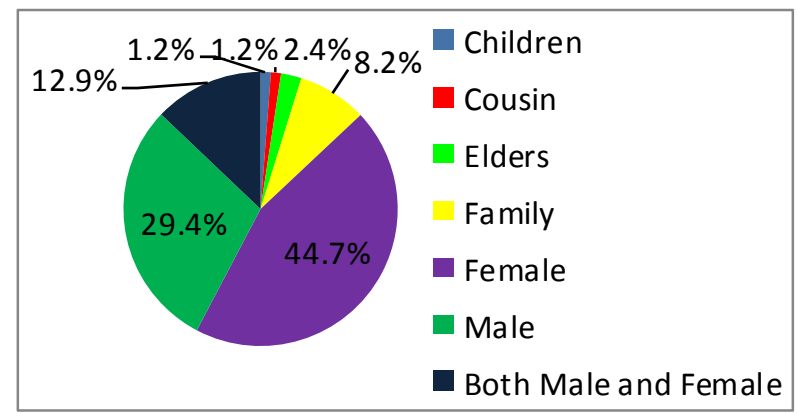

Figure 11. Management of household income in Vaiaku, Senala and Tumaseu villages, Tuvalu in year $2012(n=99)$. dicate that in Tumaseu village 43 households are headed by males and 10 households by females. Even though most of the households were headed by males in majority of the households' females managed the household income. Figure 12 below displays major household expenses.

The major household expense in Vaiaku, Senala and Tumaseu village was food as shown by 88.6 percent of the survey respondents, followed by energy (5.7 percent), education (2.3 percent), healthcare (2.3 percent) and water (1.1 percent). In Tuvalu most of the food items are imported from other countries and are expensive hence buying food items contributes to most of the household expenses. The households have to pay for electricity and purchase fuel for cooking. Primary school education is free in Tuvalu; however, for further education money is required. For Vaiaku and Senala villages the children have to travel to Vaitupu Island for secondary school education which has travel expenses, boarding costs, school fees and book costs. In times of drought some households have to purchase water.

\section{Discussion}

From the results it can be noted the respondents from Tuvalu study sites have attained more education than those from Vanuatu study sites. The level of education in Tuvalu sites was from no school to master's level while at Vanuatu sites it was from no school to secondary schools (see Sections 4.1 and 4.2).

The average household income for Vanuatu sites was US\$ 11,781 (1060351 Vatu). For the Funafuti study sites the average household income for the respondents was US\$ 7533 (AUD\$ 7357) and for Tumaseu village the average household income for the respondents was US\$ 4589 (AUD\$ 4477). The sources of household income in Vanuatu study sites was mainly from sales of products, followed by own business and wages salary (only in Piliura village) (see Section 4.1). While the major source of household income in Tuvalu sites was from wages/salary. In Funafuti, sales of products were the major source of household income for 9.6 percent of the household

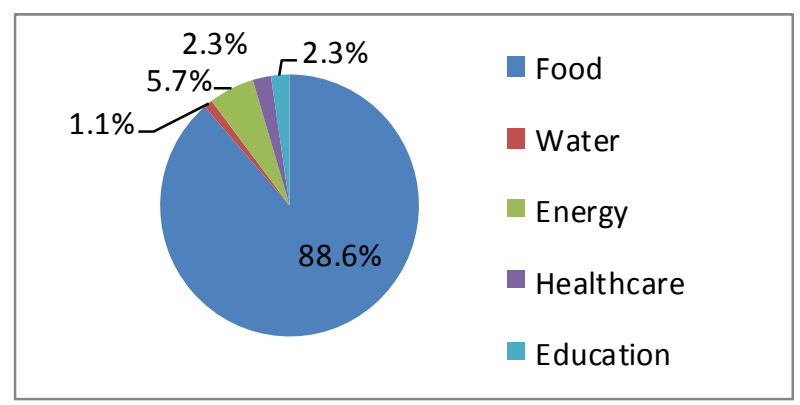

Figure 12. Major household expenses in Vaiaku, Senala and Tumaseu villages, Tuvalu in year $2012(n=99)$. 
Table 2. Chi-square p values for the variables tested.

\begin{tabular}{ccc}
\hline Variable tested & Pearson Chi-square p value-Vanuatu & Pearson Chi-square p value-Tuvalu \\
\hline Source of income and household expenses & 0.332 & 0.000 \\
Education level and source of income & 0.405 & 0.583 \\
Education level and management of household income & 0.596 & 0.980 \\
\hline
\end{tabular}

surveyed while in Tumaseu village 33.3 percent of the households earned a living from sales of products. Other sources of income were from own business, remittances and land lease.

The management of household income in Vanuatu sites was largely by males while at Tuvalu study sites mainly females managed the household income. The major household expenses in Vanuatu study sites were food (62.2 percent), education, health and transport. In Tuvalu, food (88.6 percent) was also the major household expense followed by energy, health, education and water. As discussed in Section 4.2 in Tuvalu, most of the food items are imported from other countries and are expensive hence buying food items contribute to most of the household expenses.

Moreover, a Pearson Chi-square test for independence was conducted to find out if there is any statistically significant association between some of the categorical variables of the research. The null hypothesis was set to be that statistically there is no significant association between the two variables. While the alternative hypothesis was set to be that statistically there is significant association between the two variables. From the $p$ value of Pearson Chi-square test it can be found out if there is any statistically significant association or no. If the $\mathrm{p}$ [Asymp. Sig. (2-tailed)] value is less than 0.05 the null hypothesis will be rejected and alternative hypothesis will be accepted and vice versa at five percent significant level. Table 2 shows the variables tested and the chisquare $\mathrm{p}$ values.

The Pearson Chi-square p value of, "source of income" and "household expenses"; "education level" and "source of income"; "education level" and "management of household income"; "management of household income" in Vanuatu were more than 0.05 and so there was not sufficient evidence to reject the null hypothesis hence it was accepted. Therefore, statistically there is no signifi- cant association between the variables tested above.

While for Tuvalu the variables "source of income" and "major household expenses" the Pearson Chi-square value was 0.000 which is less than 0.05 , therefore there is sufficient evidence to reject the null hypothesis and accept the alternative hypotheses. That is statistically there is significant association between the two variables. For those who have no income, food is the major household expense, for those who earn a living from wages and salary most show major household expense as food, some for energy as they have money to pay for electricity so use electricity and some for healthcare. For those with own business some showed food as major household expense, some for health care and some education. For the households that earn a living from sales of products major expenses are food and education only. The households whose main source of income was from land lease, food is the major household expenses and for few it is energy. For the families who generated their income from remittance water was major household expense. The main association between the two variables was that food remained the major household expense regardless of source of income.

On the other hand, the Pearson Chi-square p value of variables: "education level" and "source of income"; "education level" and "management of household income" in Tuvalu was more than 0.05 hence there was not sufficient evidence to reject null hypothesis hence it was accepted. Therefore, statistically there is no significant association between the variables tested above.

\section{Conclusion}

In conclusion it can be noted that source of income differs between rural and urban areas in PICs. For instance, the rural areas of Vanuatu, Piliura and Tassiriki village generate their source of living from sales of products. While in Funafuti (Tuvalu) which has urban facilities, the major source of living is from wages/salary. Tumaseu village (Vaitupu Island) has some urban facilities as noted in Section 2, hence the villagers generate income from sales of products and wages/salary. Major household expenses keep food items for all the study sites. In Tuvalu, most of the food items are imported hence they are very expensive to obtain. In Vanuatu study sites, the household income is mainly managed by males. For Tuvalu study sites, females manage the household income mainly however a significant number of males also manage the household income.

\section{Acknowledgements}

A sincere acknowledgement is extended to Dr. Karen McNamara, Prof Elisabeth Holland, and Dr. Helene Jacot Des Combes-Pacific Centre of Environment and Sustainable Development, University of the South Pacific, USP European Union Global Climate Change Alliance Project (USP-EUGCCA) for funding this research; USP- 
EU GCCA in Country Coordinators: Mr. William Arudovo (Vanuatu) and Mrs. Teuleala Manuella Morris (Tuvalu); Mrs. Kale Tuengeri Kaitu (Research Assistant in Tuvalu); Dr. Roy Smith (Nottingham Trent University) and communities in Vanuatu (Tassiriki village and Piliura village) and Tuvalu (Vaiaku village, Senala village and Tumaseu village).

\section{REFERENCES}

[1] Australian Bureau of Meteorology and CSIRO, "Climate Change in the Pacific: Scientific Assessment and New Research.” Volume 2, Country Reports, Pacific Climate Change Science Program, 2011.

[2] Vanuatu Government and United Nations Development Programme, "Vanuatu Millennium Development Goals Report,” 2013.

http://www.ausaid.gov.au/countries/pacific/vanuatu/Docu ments/vanuatu-mdg-report-2010.pdf

[3] D. Blake, "Vanuatu High Commissioner-Country Profile," 2013.

http://www.diplomaticandconsular.com/index.php?option =com_content\&view=article\&id=806\&catid=224\&Itemid $=29 \&$ act $=$ cp

[4] Vanuatu National Statistics Office, "National Population and Housing Census: Summary Release," Vanuatu National Statistics Office, Ministry of Finance and Economic Management, Port Vila, 2009.

[5] Department of Forests Vanuatu, "Vanuatu Forest Policy 2011-2020,” Department of Forests, Nicosia, 2011.
[6] A. Briney, Geography of Vanuatu,” 2013. http://geography.about.com/od/vanuatumaps/a/vanuatuge ography.htm

[7] S. L. Hemstock, “The Potential Role of Biomass Energy in the Sustainable Development of Small Island Economies: The Case for Tuvalu,” In: J. R. Pillarisetti, S. Y. Teo, R. Lawery, S. A. Siddiqui and A. Ahmad, Eds., Small Economies and Global Economies, Chapter 6, Nova Science Publishers, New York, 2008, pp. 1-19.

[8] Government of Tuvalu and UNDP, "Tuvalu Millennium Development Goals Progress Report," Department of Planning and Budget, Ministry of Finance and Economic Development, Government of Tuvalu, Vaiaku, Funafuti, 2011.

[9] “New Zealand Ministry of Foreign Affairs and Trade," 2013. http://www.mfat.govt.nz/Countries/Pacific/Tuvalu.php

[10] Tuvalu Central Statistics Division, "Tuvalu Statistics at a Glance,” 2013. http://www.spc.int/prism/tuvalu/

[11] Government of Tuvalu (a),’Funafuti Island Profile,” Department of Rural Development, Ministry of Home Affairs, Funafuti, 2012.

[12] Government of Tuvalu (b), "Vaitupu Island Profile," Department of Rural Development, Ministry of Home Affairs, Funafuti, 2012.

[13] P. Malhotra, R. C. Neudoerffer and S. Dutta, "A Participatory Process for Designing Cooking Energy Programmes with Women,” Biomass and Bioenergy, Vol. 26, No. 2, 2004, pp. 147-169. http://dx.doi.org/10.1016/S0961-9534(03)00083-7 